\title{
La verdad primera En torno a la filosofía primera de A. González
}

Recientemente Antonio González publicó el libro Estructuras de la praxis:

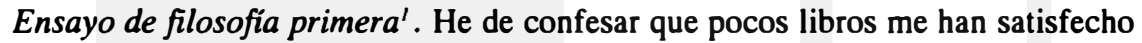
tanto intelectualmente como éste. Hasta su lectura algunos escollos me parecían insalvables impidiendo una navegación filosófica con un rumbo más decidido: no acertaba a ver cómo era posible hoy desarrollar una filosofía sin supuestos sin caer en algún género de dogmatismo; y por otro lado abandonado al marasmo del relativismo en el fondo me parecía que el discurso filosófico sonaba a hueco; infatuado con palabras añejas no era más que un género de mala literatura. Tampoco veía cómo la filosofía primera zubiriana podía tener alguna relevancia para una filosofía de la liberación, pues al fin y al cabo con Ellacuría, Dussel, Argote y otros conocedores de la filosofía zubiriana era su antropología o metafísica lo que se destacaba como neurálgico para los intereses a menudo prácticos de la filosofía latinoamericana. La filosofía primera tiende a verse en el mejor de los casos como un ejercicio europeo, académico sin relevancia práctica, y en el peor como una fuga y una abstracción de los conflictos reales. Más en Latinoamérica que en Europa, se propende a pensar que una filosofía interesada por cuestiones últimas o de fundamentación que no sea directamente política o que no sirva para la resolución inmediata de los problemas, refleja un prejuicio de clase o eurocéntrico. Es evidente que si uno está metido en los conflictos y está rebasado continuamente por las urgencias y premuras del presente, difícilmente puede hallar la serenidad de espíritu para este tipo de investigaciones. Pero tenemos que hacer un esfuerzo metodológico para prescindir en una reflexión radical de estos conflictos. Parece inmoral, ilegítimo, oscuro, inútil, una reflexión fundamental en un contexto asediado por la violencia y la miseria de muchos y, sin embargo, el libro de A. González es una muestra palpable de cómo, si es verdad que un grano de verdad es preferible a toda una 
cosecha de ilusiones, esta reflexión puede ser una forma de compromiso radical con todos aquellos que revelan la mentira de los valores vigentes en sus cuerpos demacrados. El hecho de que la reflexión filosófica no produzca una utilidad inmediata es quizás más una ventaja que un defecto, pues esta predilección por lo práctico e inmediato podría ser una de las principales armas para no ir jamás a las raíces de los problemas. Es posible que una filosofía primera no tenga influencia alguna en un mundo lastrado por el poder, las urgencias y un estrés que nos imposibilita a menudo una reflexión mínima. Sin embargo, si aceptamos que la filosofía es precisamente aquel saber que no tiene que justificarse mas que ante sí mismo, entonces no tiene tampoco por qué preocuparse por su eficacia o su indefensión ante una razón cínica. Ésta es toda la grandeza y toda la miseria de la verdad filosófica.

No me impresiona menos tampoco el carácter austero, denso, claro y diáfano que tiene el libro. No me queda ninguna duda conociendo la prolífica obra de Antonio González, aunque como en Zubiri la mayor parte de ella está constituida por cursos inéditos que apenas repite, que nos encontramos ante un talento filosófico singular. En mi caso, consciente de mis limitaciones y con un trabajo más que suficiente por delante en el mero intento de pensar las cosas al hilo de lo que han pensado otros, he de confesar que la asistencia a los cursos de Antonio y la lectura de sus artículos y de su tesis doctoral me colman del todo. Recibo alborozado todos sus nuevos artículos y apenas tengo tiempo de digerir y ponerme al día con toda su producción. También sucede que cuando por fin he llegado a comprenderle siguiéndole en una determinada dirección el ya está de vuelta. Supongo que es lo que sucederá a todos los que han tenido la suerte de gozar con la cercanía de algún genio creador, muy raros por cierto en una edad tan joven, al menos en filosofía primera, lo que no hace más que augurar su extraordinario porvenir filosófico. Pero como le gustaba decir al ex rector de la UCA de Managua, P. Xavier Gorostiaga, más importante que el talento es el talante. Y el talante de A. González invita precisamente a filosofar, a discutir, a pensar los problemas mismos abandonando todo criterio de autoridad y apuntando en certera estocada al meollo de las cuestiones a menudo embozadas en un sinfín de sendas perdidas y de estudios historiográficos, contextuales y etimológicos en los que a menudo se acaba olvidando el problema filosófico mismo.

Si la filosofía quiere proceder realmente en forma radical, tiene que conquistar primero su punto de partida. En esto se diferencia de las ciencias positivas. Cada una de ellas posee un campo donde comienza a moverse. La filosofía, en cambio, tiene que conquistarlo palmo a palmo filosofando. Ésta es su situación paradójica. Antes de comenzar a ser una investigación concreta de un terreno determinado, tiene que filosofar; filosofar sin poseer todavía un objeto seguro del filosofar. La partida decisiva de toda filosofía se juega en su punto de arranque. Como no podía ser menos en un discípulo de Zubiri, Antonio González empalma con el ámbito abierto por Husserl y proseguido de formas dispares por 
Heidegger y Zubiri. Creo que es imposible una comprensión cabal del libro de A. González sin sentar en cierto modo a Husserl, Heidegger, Zubiri y a él mismo en una misma mesa para discutir de nuevo con radicalidad este punto de partida.

Antonio González no se limita a estudiar, comentar o glosar a estos autores sino a defender con rigor filosófico frente a éstos una tesis decisiva: que la filosofía primera es una filosofía de la praxis, una praxeología. Como inmediatamente señala A. González: "muchas afirmaciones filosóficas sobre el carácter primordial de la praxis suelen estar cargadas de dogmatismo, de antiintelectualismo y de una enorme imprecisión. Estas páginas quieren mostrar que la primordialidad de la praxis se ha de mantener justamente en nombre del rigor y de la radicalidad propios de la verdadera filosofía"2. Aún tengo dudas sobre ello, y algunas de estas dudas son las que esbozo aquí en este pequeño ensayo fruto del curso de filosofía primera que impartió Antonio González en Managua y que seguí casi conteniendo la respiración. Tomando en serio el radicalismo de Zubiri, Antonio González pretende replantear el problema del punto de partida de la filosofía en un plano más hondo. ¿Lo consigue realmente? En lo que sigue apunto algunas de mis perplejidades.

El acceso a una verdad primera fuera de toda duda y asequible para cualquiera más allá de su cultura, tradición y religión tendría incuestionablemente un gran valor. En primer lugar por su interés crítico y gnoseológico. Nos podríamos hacer fuertes en algo más que en un nuevo punto de vista, en algo que no es una interpretación más. El escepticismo al que nos inclina la enorme diversidad y disparidad de teorías epistemológicas y metafísicas no podría ser absoluto y aunque como todo conocimiento sería siempre susceptible de utilización ideológica, en la persecución y delimitación de esta verdad primera nos hallaríamos ante el conocimiento menos ideológico posible que se puedan derivar y de nuestros intereses más inmediatos. En segundo lugar poseería una gran relevancia ética y política. La fundamentación de los valores éticos no dependería en último término de los poderes de turno ni de las teorías antropológicas, biológicas o cosmológicas, siempre provisionales y discutibles. No nos veríamos forzados a realizar continuas extrapolaciones éticas de los conocimientos científicos. Y hallar una universalidad elemental sería altamente incómodo para el actual orden mundial. En el orden vigente es decisivo mantener una fragmentación política y cultural que legitime las vastas disparidades económicas y jurídicas. Una verdad primera nos permitiría un genuino diálogo intercultural y un talante vigoroso para enfrentar la enormidad de los problemas planteados en nuestra época (económicos, políticos, ecológicos, bioéticos, tecnológicos, culturales, de género) sin aferrarse inmediatamente a los dogmas, a las tradiciones de cada cual y sin esperar la definitiva imposición mundial de la cultura occidental como única 
condición de posibilidad para el acuerdo entre todos los seres humanos. En tercer lugar detentaría un gran valor por sí mismo. En este intento la filosofía sería máximamlente fiel a sí misma. El acceso a una verdad primera realizaría de algún modo los ideales y anhelos que ha expresado la filosofía desde sus orígenes. No sería necesaria la "reconversión" de la filosofía, su disolución en un discurso literario, estético o moralista, ante la ausencia de objeto y el fracaso en la obtención de resultados.

En fin, no parece que haya que convencer a nadie sobre las ventajas de acceder a una verdad primera. La cuestión es si ello es posible. Las críticas a este intento de algunas filosofías que se autocalifican de postmodernas son hasta cierto punto menores. Richard Rorty, por ejemplo, aboga por convertir a la filosofía en un comentario cultural, apostando a que en un mundo sin filosofía, un mundo donde nadie pueda apelar precisamente a una "verdad primera" será un mundo mejor que el actual donde algunos creen "actuar de manera más racional, científica o seria que los demás"3. La pretensión misma de la filosofía de fundamentar los otros saberes implicaría un grave etnocentrismo cultural, pues no en vano sería ella misma uno de los inventos más sofisticados de la tradición occidental. Un amma ideológica excelente para situarse en una relación de superioridad con las demás culturas incapaces de situarse en una perspectiva universal. La tesis central de Rorty es que "en lo más profundo de nosotros no hay nada que nosotros no hayamos depositado, ningún criterio que no hayamos creado al dar a luz una práctica, ningún canon de racionalidad que no apele a dichos criterios, ni argumentación rigurosa que no obedezca a nuestras propias convenciones"4. De un modo algo tangencial se podría decir que ya es de por sí algo sospechoso un pensamiento que esté tan en ósmosis con la cultura imperante, pero lo decisivo es que en la medida en que Rorty discute y entra en el debate filosófico, en la medida en que considera que hay mundos "mejores" y "peores" es que defiende algunos criterios, que sus tesis tienen pretensión de verdad, y que alguna ejercerá como verdad primera, con lo cual contradice su afirmación central de que nadie puede apelar a ningún criterio de verdad. Además Rorty parece suponer como requisitos de una verdad primera presupuestos platónicos y aristotélicos, elementos estáticos, fijos y eternos, cuando de hecho la única condición de una verdad primera es que sea accesible para cualquiera independientemente de que sea una u otra o de que se acerque más a las tesis pragmáticas que a las platónicas. Por último, no está dicho que la filosofía sea exclusivamente una tradición occidental y que no pueda trascender de algún modo su propia tradición. De hecho, algunos de los que cultivan esta tradición (Nietzsche, Marx, Levinás, Zubiri, etc.) parecen, con todo su etnocentrismo, mucho más críticos y distantes respecto a Occidente y su historia que el mismo Rorty. Y es que la crítica de Rorty a la pretensión universalista de la filosofía, que podría haber sido muy relevante cuando dan inicio y se están llevando a cabo los procesos de colonización tiene un efecto boomerang en el momento en que éstos culminan. Hoy, la principal 
arma etnocéntrica de los países ricos es la exaltación de la fragmentación y la diferencia, la preservación de las identidades culturales sin mezcla y la creencia en las fases de desarrollo de los pueblos, para esconder que ya estamos conformando una única sociedad mundial con todos los derechos de ciudadanía y las responsabilidades que ello implica en la teoría social más anodina. Cuanto más fragmentaria es la teoría más universal es el sistema.

Una crítica más grave la constituye la apreciación de que la filosofía hasta ahora ha fracasado en el intento de acceder a una verdad primera. Existen tantas "verdades primeras" que ello debería bastamos para desistir de buscarla. Ciertamente esta estimación nos invita a la cautela y a la humildad, pero el hecho de que no se haya conseguido establecer una verdad primera en el pasado no es una razón definitiva para que no se pueda conseguir en el futuro. Asimismo, si mostráramos que en los dos mil quinientos años de tradición filosófica hay un mínimo progreso ${ }^{5}$ en la precisión de esta verdad podríamos albergar mayores esperanzas. Sin embargo, las críticas más demoledoras, y que por ello merecen un mayor grado de atención, provienen del racionalismo crítico y de las filosofías hermenéuticas. Sus reparos, como veremos, no dejarán a "la verdad primera" intacta.

\section{Las aporías del trilema y el círculo hermenéutico}

Hans Albert plantea que toda búsqueda de fundamentación, de un saber absoluto, de un punto arquimédico' ${ }^{6}$, de una verdad primera fuera de toda duda en filosofía, nos aboca a tres aporías, que por analogía con las disparatadas aventuras del barón Münchhausen, bautiza como trilema de Münchhausen? :

1. Un regreso infinito, que parece estar dado por la necesidad de remontarse siempre en la búsqueda de fundamentos, pero que prácticamente no es realizable y que por eso no provee ningún fundamento seguro.

2. Un círculo lógico en la deducción, que surge por el hecho de que en el procedimiento de la fundamentación se recurre a enunciados que ya antes se habían mostrado como enunciados que requieren fundamentación y que igualmente tampoco conducen a un fundamento seguro porque es lógicamente defectuoso.

3. Una interrupción del procedimiento en un punto determinado, que si bien parece realizable en principio implicaría, sin embargo, una suspensión arbitraria del principio de fundamentación suficiente. Un dogmatismo más o menos larvado.

La solución del racionalismo crítico a estas aporías es la de negar que exista una verdad primera. No hay punto de partida que valga, sólo hay la posibilidad de un continuo examen crítico de los enunciados ateniéndonos al principio del falibilismo ilimitado por el que se afirma que todo es inseguro. Pero este principio es para el racionalismo crítico un punto de partida incuestionable, con lo 
cual nos pilla de lleno el primero de los cuemos del trilema. Nos lo muestra muy bien $\mathrm{Apel}^{\mathbb{8}}$ mediante el siguiente diálogo imaginario entre un racionalista crítico $(\mathrm{R})$ y un oponente $(\mathrm{O})$ :

R: "El principio dice que todo es inseguro".

O: "Pero, ¿es seguro que todo es inseguro?".

R: "No, eso también es inseguro".

O: "Pero, ¿es seguro que es inseguro que todo es inseguro?".

Hans Albert contesta a esta objeción trasladando su principio o tesis fundamental del status de un dogma $\longrightarrow$ si se quiere de una evidencia- al de una hipótesis ${ }^{y}$, pero estamos en las mismas:

R: "Afirmo como hipótesis que todo es inseguro".

O: "Esto si lo sabes con seguridad: que afirmas como hipótesis que todo es inseguro".

R: (Para ser consecuente con su hipótesis tiene que contestar:) No tampoco es seguro que yo afirme como hipótesis que todo es inseguro".

Y así sucesivamente.

De ese modo nos damos cuenta de que aunque parezcan radicalmente críticas, las tesis del racionalismo crítico sólo adquieren sentido si implican algún tipo de metafísica, bien una metafísica pragmática en la que se da por supuesto que lo útil es el principio rector y que es provechoso considerar las cosas así, bien a una metafísica kantiana en la que siempre nos vamos aproximando asintóticamente a las cosas en sí ${ }^{\prime \prime \prime}$, con lo cual nos pilla el tercero de los cuernos.

Pareciera entonces que la única alternativa para no caer víctimas de alguno de los tres cuemos del trilema de marras es la que nos brinda la filosofía hermenéutica y que ya anunciaba San Agustín: Creer para comprender. Hay que creer para comprender y hay que comprender para creer. Desde esta asunción el racionalismo crítico será todo lo legítimo que se quiera, pero siempre que reconozca que es una tradición filosófica más tan adecuada como otra cualquiera. No debemos engañamos. Aquí no nos pilla el toro porque reconocemos que vivimos permanentemente ensartados en sus cuemos. De alguna manera la filosofía abdica de sus intenciones originales que era la búsqueda de un saber universal y primero para disolverse en teología, literatura o comentario de una determinada tradición. Es algo que ya evoca la misma etimología de la palabra hermenéutica. Si ya es bastante significativo que las tradiciones filosóficas hermenéuticas procedan del campo de la teología, especialmente de la teología protestante" ${ }^{11}$ en sus mismos orígenes griegos, al evocar el nombre del Dios Hermes como mensajero de los dioses o intérprete de los mensajes del hado, ya se contempla esta subordinación de la filosofía a un saber exterior a la misma. La filosofía no sólo reconoce su fracaso, sino que defiende la imposibilidad de mantener cualquier 
propósito de autonomía. Sabiéndolo o no, y peor cuando no se sabe, la filosofía siempre implicaría una profesión de fe.

La filosofía hermenéutica nos mostraría, de manera contundente, que todas aquellas filosofías que tienen como pretensión fundamental superar la tradición constituyen precisamente una tradición más. Una tradición cuyo presupuesto o prejuicio fundamental es "el prejuicio contra todo prejuicio"12. Es precisamente en esta tradición ilustrada donde el término "prejuicio" adquiere el sentido peyorativo vigente de juicio falso o sin fundamento. Este presupuesto ilustrado llevará a establecer una oposición impropia entre razón y tradición, pues lejos de ser irreductibles sólo puede haber un ejercicio racional en una tradición en la que siempre estamos y que ejerce una autoridad anónima en las costumbres y la educación. En la misma investigación científica resuena siempre la tradición ya que es imposible cualquier enunciado, incluso aquel que pretenda plasmar la observación más simple que no esté cargado de teorías. Toda crítica de la tradición pende siempre de una u otra tradición o de algunos valores de la misma que aborrecemos o consideramos ejemplares. Este presupuesto impide además una comprensión adecuada de la finitud humana ${ }^{13}$, que tiene como condición intrínseca positiva suya el estar inmersa en tradiciones y prejuicios. Una razón absoluta no es una posibilidad de la humanidad histórica y los prejuicios no constituyen, por tanto, una limitación de la libertad sino su condición. Gadamer ve como tarea más inmediata frente a la filosofía ilustrada el desembarazar los prejuicios de su aureola repulsiva para devolverles su dignidad y su condición humana.

La única posición honesta que nos quedaría, si seguimos interesándonos por la literatura filosófica, es apostar por una determinada tradición o escuela filosófica enunciando claramente nuestros presupuestos. Es lo que nos sugiere P. Ricoeur: "Esta apuesta se convierte entonces en la tarea de comprobarla y de saturarla en cierto modo de inteligibilidad... Al apostar por una determinada tradición apuesto al mismo tiempo que recuperaré mi apuesta en poder de reflexión, dentro del plano del raciocinio coherente"14. Sin embargo, ¿no es posible ningún otro camino? ¿Es efectivamente la posición de la filosofía hermenéutica tan honesta como se nos dice? ¿Es verdad que siempre nos movemos en el terreno del logos o éste es un ingente prejuicio en el que coinciden las filosofías más variopintas, desde la hermenéutica, hasta la filosofía analítica y las filosofías del sentido? Aunque no sabemos en este momento cuál es la contestación a estas preguntas, justo es reconocer que se trata de una cuestión decisiva. Para resolver estos problemas no nos podemos entretener en cuestiones colaterales del tipo: "la hermenéutica es de tendencia conservadora", o "la hermenéutica es el mejor antídoto contra el dogmatismo". Aquí lo que nos interesa es dilucidar la cosa misma independientemente de sus consecuencias y de nuestras simpatías morales. 


\section{De un punto arquimédico a un punto de partida pre-lingüístico}

Como en toda formulación de un problema, ganamos mucho formulándolo correctamente! Lo que nos proponemos es ver si de hecho es posible, contradiciendo los dogmas centrales de las filosofías hermenéuticas, intentar la descripción de una verdad primera accesible para cualquiera. ¿Es ello viable sin incurrir en el trilema de Münchhausen? Es más, podría muy bien ser que tal como entiende el problema Hans Albert no haya escapatoria al trilema. Lo decisivo aquí es ver qué entendemos por "búsqueda de fundamentación", "saber absoluto", "verdad fuera de toda duda" y "punto arquimédico". Estas expresiones son fuentes de continuos equívocos. Fijémonos que nuestra formulación del problema es muy diferente de la de Hans Albert.

Cuando se habla de búsqueda de fundamentos se suele sobreentender que lo que estamos buscando, ya sean impresiones, hechos positivos, datos sensoriales, universales, o verdades a priori, tiene que ser algo apodíctico y fijo, más firme si cabe que una roca, para poder ser calificadas de fundamento. Mediante esta definición se circunscribe el fundamento a algo "estático". Para evitar imprecisiones creo que es útil una distinción de raigambre zubiriana. Una cosa es la fundamentación como creación de la razón, creación de lo que pueden ser los contenidos de la realidad en profundidad, allende la aprehensión ${ }^{15}$, por ejemplo el sol ahora me acaricia la piel y en mi cultura el fundamento de ello es una teoría astronómica siempre provisional que me explica este hecho, y otra cosa es la fundamentación como intento de descripción de los hechos inmediatamente dados, el análisis de estas impresiones inmediatas que me están produciendo una sensación agradable. En el primer sentido, la cuestión del fundamento es algo siempre abiertoth. No sólo se incurre en el primer cuemo del trilema, sino que además esto es consustancial a la función esencial de la razón, a su función explicativa y fundamentante.

En el segundo sentido de fundamentación no se pretende ningún género de explicación teórica sino justamente una descripción asequible para cualquiera, independiente de la cultura, las teorías científicas y la tradición de cada cual, una descripción de la situación primigenia e inmediata en la que estamos. Se trata de avanzar, hasta donde nos sea posible, en la clarificación de esta situación "originaria". Y esto tiene cuando menos una preciosa ventaja: aunque la descripción sea mejorable aquí no está dicho que no podamos llegar a algo que sea confín, al menos es obvio que el análisis de hechos positivos ${ }^{17}$ es mucho más cerrado que la creación teórica. Por cuanto esta constatación es primera y radical, es tarea anterior a toda construcción - teoría del conocimiento, psicología, ciencia en general, metafísica - y traza el marco en el cual toda labor teórica encuentra su fundamento y su valor. En esta dirección se mueve el análisis o descripción de los hechos que es lo único que persigue Zubiri' ${ }^{18}$ y los esfuerzos de Husserl para hacer de la filosofía una ciencia estricta ${ }^{19}$. Desde esta perspecti- 
va, la primera tarea del filósofo consiste en describir lo más apegadamente posible estos hechos originarios y entonces mostrar con precisión cómo el conocimiento más complejo se apoya en él. Si esto es factible tendremos un criterio para criticar nuestro conocimiento más allá del lodazal de nuestro lenguaje o sistema de signos y lograremos una especie de conocimiento inmediato indiscutible sin incurrir en el trilema de marras. El término "fundamento" no es impropio porque aquí el fundamento apela a una instancia inmediata aprehendible para cualquiera que sostiene las teorías científicas y metafísicas indicándonos sus orígenes, sentido y límites, pero no debe confundirse con la fundamentación racional pues casi se trata de un movimiento inverso.

Por "saber absoluto" y "verdad fuera de toda duda" no entendemos un conocimiento intemporal o eterno, sino mucho más modestamente un saber primero desligado de los demás del que penden los demás saberes. Y por "punto arquimédico" no entendemos un punto inmóvil, estable y seguro, sino un punto de partida todo lo móvil, inseguro e inestable que se quiera pero que sea por su accesibilidad universal menos indudable y arbitrario que cualquier otro punto de partida.

Hechas estas precisiones podemos argüir, frente a la tesis de las tradiciones hermenéuticas que sostienen la inestabilidad de los presupuestos y frente a las paradojas del trilema, que se basan en un presupuesto carente de suficiente justificación, un presupuesto que se remonta a Aristóteles y que consiste en pensar la verdad al hilo del logos, en concebir que la inteligencia humana es constitutivamente lingüistica. Si hubiera una primera verdad que no fuera íntegramente lingüística, podríamos salir del círculo hermenéutico y de las paradojas del trilema, pues aunque la conceptuación filosófica de esa verdad primera será inexorablemente una conceptuación lingüística, esta verdad primera pre-lingüística constituiría el criterio para contrastar los presupuestos y la adecuación o no de las nociones utilizadas en la descripción de la misma.

A la tradición hermenéutica, sobre todo a Gadamer y a Ricoeur, se le concede que siempre utilizamos un lenguaje y que en este lenguaje habrá siempre presupuestos ${ }^{211}$, que es imposible acceder a una razón absoluta y a alguna situación de completa falta de presupuestos. Que la ilustración bajo su aparente criticidad mantiene auténticos dogmas. Que lo más esencial del prejuicio es que nos esté determinando sin que nos demos cuenta, y que, por tanto, están siempre latentes aún en la situación más desprejuiciada concebible. Pero se rechaza también el dogmatismo de la hermenéutica y se la rechaza justamente no desde los dogmas de otra tradición filosófica, sino desde una posición que pretende ser radicalmente antidogmática. Gadamer nos dice que: "si se quiere hacer justicia al modo de ser finito e histórico del hombre es necesario llevar a cabo una drástica rehabilitación del concepto de prejuicio y reconocer que existen prejuicios legítimos"21 y el mismo Gadamer se formula la pregunta clave: " $i$ En qué se distinguen los prejuicios legítimos de todos los innumerables prejuicios cuya 
superación representa la incuestionable tarea de toda razón crítica?"22. Pero si seguimos leyendo ávidamente esperando una respuesta clara en el asunto nos encontraremost con la terrible decepción de que no la hay. Implícitamente se asume que los prejuicios de la tradición hermenéutica son los legítimos, mientras que no lo es por ejemplo el presupuesto ilustrado de la falta de presupuestos. Si seguimos preguntando con qué criterio se establece esta distinción, la filosofía hermenéutica se ve forzada a decimos que con ninguno. Máxime podrá apelarse a la apuesta arbitraria por unos u otros presupuestos legítimos como única posibilidad honesta de seguir haciendo filosofía. Y esto no dista mucho del dogmatismo que originalmente en la historia de la filosofía significó atenimiento a una opinión o a una doctrina, sin atender a los hechos o a los argumentos que pudieran ponerla en duda $^{23}$. Más grave que esto es la sospecha de que, a fin de cuentas, los prejuicios legítimos son los que impone la tradición más poderosa, o el grupo con más poder dentro de una determinada tradición.

Ya hemos rechazado antes como presupuesto ilegítimo de las corrientes hermenéuticas el de la lingüisticidad constitutiva de la inteligencia, pero esto no lo pretendemos establecer arbitrariamente sino apelando a un criterio extralingüístico, a una verdad primera adogmática, inmediata y accesible para cualquiera, una verdad primera únicamente abordable mediante la tradición de cada cual, pero que se halla más allá de la tradición de cada cual. De ese modo, la tradición de cada uno no es la medida absoluta de los demás y las tradiciones de todos pueden ser cuestionadas recurriendo a un análisis detallado de esta verdad primera. La filosofía no podrá conseguir más que descripciones siempre provisionales de esta verdad primera, pues justamente por su carácter extralingüístico nunca es absolutamente traducible al lenguaje, pero su tarea será una permanente y siempre abierta revisión crítica de los propios presupuestos o si se quiere la distinción entre presupuestos legítimos e ilegítimos no será gratuita. Se considerará presupuesto ilegítimo en una filosofía primera a todo aquel que no se avenga a la verdad de lo inmediatamente dado en la aprehensión. Podría ser también que en este esfuerzo de eliminación de presupuestos hubiera un cierto avance, que la historia de la filosofía no fuera un puro caos de opiniones y de imaginaciones febriles ${ }^{24}$. Ahora bien, la cuestión decisiva es si de hecho hay una verdad extralinguística inmediata aprehendible para cualquiera, con independencia de su cultura, religión y costumbre, en definitiva con independencia de su logos, sin que ello signifique algo así como la pretensión de exiliarse del lenguaje, de saltar por encima de la propia sombra.

Las escuelas neokantianas dirían que esto es una ilusión y aceptando el presupuesto hermenéutico del carácter lingüístico de toda verdad, mantendrían como estrategia de salida del círculo hermenéutico la apelación a las condiciones de posibilidad del lenguaje que al no tener la inmediatez de la verdad primera justo es reconocer que no podrán tener nunca su claridad y firmeza. Muchas otras corrientes filosóficas verán esta cuestión como muy abstracta cargando muy 
rápidamente con sus propias metafísicas, o criptometafísicas que es peor, sin hacerse mucho problema de ello. Especialmente el segundo Wittgenstein nos hará ver que la función significativa que tiene la palabra queda establecida por el uso público del lenguaje, de tal manera que no sólo el acto intencional de significar es superfluo, sino que apenas cuenta con la posibilidad de imponer su intención contra tal uso. Si yo en lugar de decir el Señor Suizo es suizo "pronuncio la proposición con los significados cambiados, el sentido de la proposición se deshace- en realidad se deshace para mí, no para el otro a quien hago la comunicación. Así pues, ¿qué importa este caso?"2s. Lo determinante del significado o sentido de las manifestaciones lingüísticas no es para Wittgenstein, el hecho de que al hablar nos formemos mentalmente significados, sino que dichas manifestaciones acontezcan en un juego lingüístico en el que el sentido por una parte y la comprensión del sentido por otra se hallan establecidos según unas reglas de juego de carácter público, según unas costumbres institucionalizadas. El lenguaje, los juegos lingüísticos penden así de las formas de vida. Toda proposición remite por tanto a una verdad extralingüística que como máximo podemos intentar describir, pero que nos saca del círculo hermenéutico y de toda recaída en el trilema en la medida en que esta forma de vida de la que pende toda proposición no es lingüística ${ }^{26}$. Lo inmediato en una proposición lingüística, más inclusive que su uso, es su sonoridad, su carácter físico ${ }^{27}$, su actualidad en la aprehensión.

Reconocemos, por tanto, ante la crítica del racionalismo crítico y de las filosofías hermenéuticas, que si nos movemos en el orbe del lenguaje y el sentido incurrimos necesariamente en alguna de las aporías del trilema sin posibilidad alguna de salir del círculo hermenéutico; que ningún silogismo, ningún razonamiento deductivo, ni ninguna proposición puede ser la verdad primera que buscamos; que además la verdad primera a salvo de toda duda y asequible para cualquiera no tiene por qué ser un principio absoluto en el sentido de eterno e inamovible. La única alternativa que nos queda es que la verdad primera sea extralingüística. ¿Es realmente posible acceder a ella sin ningún género de mixtificación o de aporía? Ésta es una cuestión crucial donde nos jugamos el ser o no ser de la filosofía misma, su cientificidad o su disolución en una especie de mala literatura ${ }^{28}$. Veamos, pues, cómo han accedido algunos autores a esta verdad pre-lingüística, cómo nos la han descrito, cuáles de estas descripciones parecen resistir de momento la prueba del examen más crítico, y qué dudas y perplejidades permanecen en nosotros.

\section{La impresión}

Sin muchos tapujos y poniéndose a analizar lo inmediatamente dado, Hume nos dice ya de entrada que "todas las percepciones de la mente humana se reducen a dos géneros distintos que yo llamo impresiones e ideas. La diferencia entre ellos consiste en los grados de fuerza y vivacidad con que se presentan en 
nuestro espíritu y se abren camino en nuestro pensamiento"29. Las percepciones que se imponẹ con más fuerza, violencia y vivacidad las llama Hume impresiones y esta vivacidad la tienen sólo cuando hacen su primera aparición. Por ejemplo, la computadora que tengo a la vista tiene una vivacidad, una fuerza de imposición ante mi tacto y mi vista y mi oído que no tiene cuando recuerdo que la he dejado prendida mientras salgo de la oficina. Estas impresiones son prelingüísticas. Luego por el hábito podemos reproducir estas impresiones mediante ideas simples que son asociadas a una palabra o sonido ${ }^{{ }^{*}{ }_{1}}$. Hume establece muy rápidamente una división entre impresiones e ideas y la subsiguiente concepción de que las ideas se derivan de las impresiones y las representan exactamente. Prácticamente en las treinta primeras páginas del Treatise se dilucida lo más decisivo del análisis Humeano. Y esta precipitación será también, como veremos, su gran flaqueza.

A partir de este análisis de lo que Hume considera como inmediatamente presente, irrecusable y obvio critica la idea de mundo o realidad, la idea de yo, la idea de substancia, la idea de causalidad, la idea de interioridad y la idea de identidad por ser precisamente sólo eso: ideas de las que jamás podemos tener una impresión inmediata. Así el mundo es una inferencia de determinadas percepciones: "Que nuestros sentidos no nos of recen impresiones como imágenes de algo distinto independiente y externo es evidente, porque no nos proporcionan más que una percepción única y no nos dan jamás la más mínima indicación de algo más allá de ella. Una percepción única jamás puede producir la idea de una doble existencia más que mediante alguna inferencia de la razón o de la imaginación. Cuando el espíritu se dirige más allá de lo que inmediatamente se le aparece no se puede dar razón de sus conclusiones por los sentidos y se dirige mas allá, ciertamente, cuando partiendo de una única percepción infiere una doble existencia y supone relaciones de semejanza y causalidad entre sus dos términos"31.

Tampoco el yo o la persona es jamás una impresión: "cuando penetro más íntimamente en lo que llamo mi propia persona, tropiezo siempre con alguna percepción particular de calor o frío, luz o sombra, amor u odio, pena o placer. No puedo jamás sorprenderme a mí mismo en algún momento sin percepción alguna, y jamás puedo observar más que percepciones... Si alguno basándose en una reflexión seria y sin prejuicio, piensa que tiene una noción diferente de su Yo, debo confesar que no puedo discutir más largo tiempo con él. Todo lo que puedo concederle es que tiene tanto derecho como yo y que somos esencialmente diferentes en este respecto. Puede, quizá, percibir algo simple y continuo que llame su Yo, aunque yo estoy cierto de que no existe un principio semejante en mí"32.

Pero para Hume la madre de todas las inferencias ilegítimas es la idea de causalidad, de ella penden de algún modo las demás: "Me doy cuenta de que, de todas las paradojas que he expuesto o que tendré ocasión de exponer en el curso 
de este tratado, la presente es la más violenta, y que solamente a fuerza de una prueba sólida y del razonamiento puedo esperar que sea admitida y venza los prejuicios inveterados del género humano. Antes de que nos reconciliemos con esta doctrina cuántas veces debemos repetimos a nosotros mismos que la simple consideración de dos objetos o acciones, aunque relacionados, no puede damos una idea de poder o conexión entre ellos; que esta idea surge de la repetición de su unión, que la repetición no descubre nada en los objetos, sino que tiene tan sólo influencia en el espíritu por la transición habitual que produce; que esta transición habitual es, por consiguiente, idéntica al poder y necesidad, que son, por consecuencia, cualidades de percepciones, no de objetos, y son sentidas internamente por el alma y no percibidas externamente en los cuerpos".3.3. "La necesidad del poder que une las causas y efectos radica en la determinación del espíritu a pasar de los unos a los otros"3.

A partir, pues, de lo que pretende ser efectivamente un análisis radical y escrupuloso de la verdad primera Hume desemboca en un escepticismo racional no sustentable en la vida práctica: "Si se me preguntase si soy realmente uno de estos escépticos que tienen todo por incierto y que nuestro juicio no posee ninguna medida de verdad o falsedad en ninguna cuestión, replicaré que esta cuestión es enteramente superflua y que ni yo ni ninguna otra persona mantuvo sincera y constantemente esta opinión. La naturaleza, por una necesidad absoluta e inverificable, nos ha llevado a juzgar lo mismo que a respirar y a sentir, y no podemos evitar el considerar a ciertos objetos con mayor o menor seguridad por razón de su enlace habitual con una impresión presente que el ver los cuerpos que nos rodean cuando dirigimos los ojos hacia ellos en pleno sol. Todo aquel que se ha tomado el trabajo de refutar las cavilaciones de este escepticismo total ha luchado sin tener un enemigo y ha tratado de establecer por argumentos una facultad que ha sido ya antes implantada en el espíritu y hecha inevitable... Todos nuestros razonamientos relativos a las causas y efectos no se derivan más que del hábito y que la creencia es más exactamente un acto de la parte sensitiva que de la cogitativa de nuestra naturaleza"3s. "Felizmente, la naturaleza destruye a tiempo la fuerza de todo argumento escéptico y le impide tener una influencia considerable sobre el entendimiento"3.3.

En este tipo de aseveraciones de Hume donde constituye la naturaleza como la verdadera razón de nuestras teorías metafísicas, vemos ya una anticipación de la metafísica Nietzscheana del instinto, la vida y el cuerpo. La llamo metafísica nietzcheana, porque por más que consideremos que ofrece una mayor capacidad explicativa que otras tesis metafísicas, no deja de ser una hipótesis que no encontramos en el análisis de lo inmeditamente dado. Justo es reconocer que si nuestras respuestas a Hume no son más rigurosas que sus propios argumentos, será más honesto intelectualmente quedarnos con su escepticismo racional, por mas insatisfactorio que lo encontremos, que vender como verdadero lo que no es más que otra creencia u otro punto de vista. 
La primera objeción que podemos hacer al análisis de Hume es que no está nada claro que jos contenidos de una impresión tengan mas vivacidad que los contenidos de una idea. Por ejemplo, cuando sueño la idea se me impone con tal fuerza y violencia algunas veces que me despierto contentísimo de saber que estaba soñando. Del mismo modo, el recuerdo (idea) de alguien querido puede tener tal grado de vivacidad que convierta en débiles y ligeras lo que Hume llama impresiones. Es tan fácil de rebatir esta división establecida por Hume que podemos acusarlo de una cierta precipitación en un asunto tan decisivo en toda su obra. Ciertamente Hume intuye la dificultad: "Así en el sueño, en una fiebre, la locura o en algunas emociones violentas del alma nuestras ideas pueden aproximarse a nuestras impresiones del mismo modo que, por otra parte, sucede a veces que nuestras impresiones son tan débiles y tan ligeras que no podemos distinguirlas de nuestras ideas. Pero a pesar de esta próxima semejanza en pocos casos, son en general tan diferentes que nadie puede sentir escrúpulos alguno al disponerlas en dos grupos distintos y asignar a cada uno un nombre peculiar para marcar esta diferencia" ${ }^{37}$. Es curioso que Hume, tan riguroso en sus afirmaciones, pase tan rápidamente por encima de una división y de unas dificultades que él mismo ha avizorado. Esto no puede más que prevenirnos contra la fuerza de los prejuicios y de los presupuestos metafísicos aún allí donde más gala se hace de rigor y escrupulosidad en el análisis.

La segunda dificultad, muy ligada a la primera, consiste en su afirmación de que toda idea procede de una impresión. Podríamos poner muchos ejemplos que nos hacen dudar de esto, el mismo que pone Hume es contundente: "Supongamos que una persona haya llegado a conocer los colores de todas clases, excepto un matiz de azul particular. Colóquense todos los diferentes matices de este color, excepto ese único, ante él, descendiendo gradualmente del más oscuro al más claro; en este caso, es manifiesto que percibirá un hueco donde falta este matiz y se dará cuenta de que existe en este lugar una distancia mayor entre los colores contiguos que en algún otro; Me pregunto ahora si es posible para él suplir por su propia imaginación esta falta y producir la idea de este singular matiz. Creo que sí" ${ }^{34}$, pero inmediatamente subraya Hume que el caso es tan singular que no merece nuestra atención. La afirmación de que una impresión es más inmediata que una idea y que las ideas derivan de la impresión sólo podemos hacerla asumiendo determinados presupuestos metafísicos. Tan inmediato es un número o un recuerdo, como la percepción de un color, o de un determinado dolor. Si Hume privilegia lo segundo respecto a lo primero es por un prejuicio sensualista, por la asunción de una metafísica empirista que entre otras cosas acepta ingenuamente una división teórica entre sentir e inteligir y la consecuente primacía de la sensibilidad (impresión) sobre la intelección (idea).

El tercer inconveniente estriba en que Hume da por supuesta la escisión cartesiana entre mundo exterior y mente, para declarar luego como imposible o fuera de lugar cualquier conexión entre ellos. Asume de entrada una división 
entre sujeto y objeto que no está sin más justificada. "Las actividades de la naturaleza son independientes de nuestro pensamiento y razonamiento, lo concedo"39. Este dualismo se refleja luego en paridades muy discutibles si nos atenemos a lo dado inmediatamente: "interioridad-exterioridad", "naturaleza-espíritu" etc."

El cuarto escollo consiste en la confusión de Hume entre el análisis de lo inmediatamente dado y la experiencia interna, entre unos datos que hay que analizar cuidadosa y desprejuiciadamente en una actitud filosófica radical y la naturalización y presuposición de que estos datos son datos psíquicos sin cuestionar la actitud natural e ingenua ${ }^{4 t}$. Dicho de otro modo, Hume inadvertidamente no es fiel a la descripción de lo dado, sino que le aplica una teoría psicológica por la cual estos datos son datos internos, interiores, datos del espíritu. Hume coloca elementos en la aprehensión, sin haberlos encontrado analíticamente, hace afirmaciones que van mas allá de lo inmediatamente dado en la aprehensión. Afirmaciones que penden de sus prejuicios metafísicos y no de un atenimiento riguroso a lo dado.

La quinta objeción es que cada impresión es conceptuada por Hume como una especie de mónada sin ventanas, como átomos, como unidades estrictamente individuales, por eso no tiene problema en atribuir en un determinado momento la definición de substancia a cada impresión ${ }^{42}$. Esta cosificación de la impresión hace, por así decirlo, que la apreciemos como una congelación de algo que es esencialmente procesual, dinámico, continuo, abierto. Es decir cada impresión -el árbol que veo en este instante, el tacto del teclado de la computadora, etc.-, si nos atenemos a lo inmediatamente dado, aparece con una intrínseca apertura a toda otra impresión.

La sexta dificultad consiste en que la afirmación de que la unión de las causas y de los efectos radica en la costumbre se desliza también a algo que está más allá de la impresión misma. Lo que deberíamos preguntamos es si en la impresión misma hay algo que nos incline a establecer relaciones de causalidad entre las diferentes impresiones y quizás no colegir tan rápidamente como Hume la absoluta inconexión de las impresiones. Como ésta es la madre de todas las falsas inferencias, si demostramos que surge de un análisis insuficiente de Hume entonces tendremos que corregir también sus apreciaciones sobre el yo, la substancia, la interioridad y la identidad, pues podría ser que no fueran inferencias del todo ilegítimas si encuentro en la impresión misma algo más que una sucesión discontinua e incomunicada de contenidos. Es lo que nos muestra el análisis riguroso de Zubiri. Ciertamente no encontramos en lo inmediatamente dado en la aprehensión una relación causal ${ }^{43}$, pero sí la funcionalidad de cada cosa. Las cosas se aprehenden unas en función de otras ${ }^{44}$. La misma sucesión o la coexistencia de cosas son tipos de funcionalidad por las que cada cosa nos remite a otra. 
El séptimo inconveniente estriba en el olvido de lo que Ortega llama el carácter ejecutivo de las aprehensiones humanas: "es preciso, pues, distinguir entre el ser ejecutivo del pensamiento y su ser objetivo. El pensamiento como ejecutividad, como algo ejecutándose y mientras se ejecuta no es objeto para sí, no existe para sí, no lo hay"45. Para que haya un pensamiento es menester que se haya ejecutado ya y que yo desde fuera de él lo contemple, me lo haga objeto... cuando sólo hay pensamiento no hay efectivamente lo en él pensado..."4h. La ejecutividad es absoluta posición. El ejemplo de Ortega es muy esclarecedor. Supongamos que sufrimos una alucinación y que de pronto vemos que entra en la clase un toro furioso, mientras se está ejecutando la alucinación lo que hay absolutamente es un toro ante nosotros y nuestro terror. Sólo cuando dejo de estar ejecutándola puedo convertir esta presencia del toro en objeto de mi pensamiento y decir que en realidad consistía en una alucinación. La ejecutividad es sinónimo de vigencia, de lo que Zubiri llamará fuerza de imposición, y sólo abandonando la descripción de los actos en su inmediatez puede olvidarse este poder ejecutivo de los mismos. Ciertamente Ortega con esta observación dirige su crítica al idealismo: "La idea misma de pensamiento o de conciencia es una hipótesis, no un concepto formado ateniéndose pulcramente a lo que hay tal y como lo hay"47. "El idealismo, al interpretar lo inmediato como pensamiento, contradice y vulnera su propio e invulnerable punto de partida. Consistía éste en exigir como carácter fundamental e inexcusable de realidad su inmediatez, su presencia y patencia ante mí. Pero es el caso que cuando yo veo esa pared es ésta lo presente y patente, pero no mi verla. Yo no veo mi ver cuando estoy viendo. Para darme cuenta de que hay mi ver tengo que dejar de ver y recordar que hace un instante veía"48. Aunque en estas afirmaciones podemos apreciar las influencias de las argumentaciones de Hume contra la idea de yo es fácil de revertirlas contra el mismo Hume, pues del mismo modo que la pura descripción de lo inmediato no da derecho a sostener que las cosas son pensamiento, subjetividad, yo, tampoco da pie a sostener que son solamente datos sensibles, y discontinuos, puras afecciones de un sujeto.

La objeción decisiva, sin embargo, es la que nos muestra Zubiri al realizar un análisis pormenorizado de la impresión. Y es que Hume sólo se fija en los contenidos de la impresión. "El calor de un fuego, aunque sea moderado se supone que existe en el fuego"49. Atribuimos existencia o realidad a algo de lo que propiamente sólo tenemos un flujo de impresiones. Hume observa que todos los objetos a los que atribuimos una existencia continua tienen una constancia y no suelen cambiar por la interrupción de mi visión ${ }^{\text {s0 }}$. Parece inobjetable que de esta constancia no podemos derivar sin más la existencia, que hay un salto injustificado entre la constancia impresiva y la realidad de la impresión allende la misma. Pero Zubiri nos hará apreciar que exista o no el fuego, que tenga realidad o no más allá de la impresión, el calor le pertenece de suyo en la impresión. En la impresión no solamente tenemos un determinado contenido 
esto es: una imagen a la que llamamos fuego, una sensación de calor y unos sonidos de la madera crepitando. Esto es verdad, pero no es toda la verdad. El crepitar, el calor y la imagen se presentan como algo en propio, de suyo en la misma impresión. Son tan de suyo que resulta más difícil reparar en la impresión misma que sumergirse en la alteridad de lo presentado ${ }^{51}$. Hume resbala o elimina uno de los momentos de la impresión, el momento de alteridad, identificando por tanto la impresión con sus contenidos. Este olvido de Hume, como veremos, tiene consecuencias decisivas.

\section{La intencionalidad}

Al decir de Husserl, Hume en su Treatise plantea los problemas más cruciales de la filosofía ${ }^{52}$ y lo considera de una profunda importancia histórica porque constituye el primer intento riguroso de fundamentación última. Husserl juzga que en Hume se halla el primer bosquejo sistemático de una fenomenología pura $^{53}$, que de algún modo rebasaba ya en su tratado el psicologismo empirista, y no dejará de elogiar la radicalidad de los empiristas que quieren hacer valer frente a la tradición, la superstición y los prejuicios de diferente índole la autoridad de las cosas mismas "interrogándolas tales cuales se dan en sí mismas, y

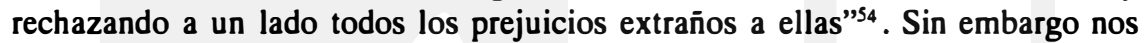
hará notar que Hume y en general los empiristas mantienen enquistados algunos prejuicios palmarios.

El principal es suponer que en la experiencia de los sentidos es el único lugar donde se dan las cosas mismas, lo cual tiene como consecuencia el reducir la vida consciente a impresiones considerándolas como cosas olvidando el sentido y el significado que se presentan inmediatamente a la conciencia. En realidad Hume no es fiel a lo dado. Abandona lo dado por una metafísica sensualista: "Afirmar rotundamente que todos los juicios requieren una fundamentación empírica es una especie de construcción a priori no justificada. En efecto, el postulado de base para todo empirismo consiste en afirmar que la experiencia es la única fuente del conocimiento. Esta afimación debe ser sometida a su vez a la prueba de la experiencia, pero como la experiencia sólo proporciona datos contingentes y particulares, no puede ofrecer a la ciencia el principio universal y necesario de una afirmación de este tipo. El empirismo no puede ser comprendido por el empirismo. El empirismo sostiene una tesis metafísica, un prejuicio que da por sentado sin más. En una filosofía primera que se precie de tal sólo cabe comprobar las afirmaciones ajustándolas lo más fielmente posible a lo dado originariamente en la aprehensión. Esto sería al menos un proceder realmente exento de prejuicios"5s.

Este análisis insuficiente de la aprehensión aboca a Hume al solipsismo, a no poder rebasar la esfera de lo inmanente, así como al escepticismo ${ }^{56}$. Un escepticismo que según Husserl no puede más que contradecirse; sin embargo, este 
argumento tradicional no afecta a Hume, pues como hemos visto anteriormente, Hume se había percatado de esta contradicción y había argumentado que el escepticismo en la vida cotidiana es una posición insostenible. Su escepticismo es en realidad una especie de vitalismo nietszcheano "avant-la-lettre". Tampoco podemos negarlo recurriendo a argumentos morales del tipo de los que a veces utiliza Husserl: “¿podemos tranquilizarnos con la enseñanza de la historia que todas las consideraciones del mundo espiritual, todas las reglas de vida, los ideales, las normas, sostenidas en cada caso por los hombres, se forman y luego se deshacen como olas fugitivas, que así ha sido y será siempre, que siempre la razón debe transformarse en sinsentido, y el bienestar en calamidad? ¿Podemos con esto tranquilizarnos, podemos vivir en este mundo cuyo acontecer histórico no es otra cosa que un incesante encadenamiento de impulsos ilusorios y amargos desengaños?"57. Nos podamos tranquilizar o no, lo decisivo en la tarea filosófica es comprobar la corrección del análisis de Hume y si realmente "las tesis fundamentales del empirismo necesitan de un previo y exacto análisis, clarificación y fundamentación" ${ }^{58}$.

La pretensión de Husserl es loable y constituye sin duda uno de los mayores acicates del ejercicio filosófico, "la búsqueda de algo accesible de una vez y para todos y de igual modo... de una verdad incondicionalmente válida partiendo de aquello que los europeos y los hindúes coinciden no obstante toda relatividad"59. "Mientras que ellos como filósofos (los empiristas) que tienen una posición determinada parten de previas opiniones no aclaradas ni fundadas, en patente contradicción con su principio de la exención de prejuicios, nosotros tomamos nuestro punto de partida de aquello que se encuentra antes de todas las posiciones posibles: del reino íntegro de lo dado intuitivamente y antes de todo pensar teórico, de todo aquello que se puede ver y aprehender directamente —cuando uno no se deja cegar por prejuicios ni apartar por ellos de fijar la atención en clases enteras de auténticos datos"(x). Una filosofía radicalmente liberadora debe mantener "la voluntad de liberarse de todos los prejuicios, exige la comprensión de que todo lo que se tiene por obvio son prejuicios, que todos los prejuicios son oscuridades provenientes de una sedimentación tradicional y no solamente de juicios de verdad incierta"61. Y es que para Husserl, los prejuicios no son sólo fruto de mantenerse en una actitud natural o dogmática como Descartes ${ }^{\text {h2 }}$ y hasta el mismo Hume, ni meros residuos de las tradiciones escolásticas, ni adiposidades casuales de la época, sino que son una especie de "supuestos naturales milenarios, cuya superación no puede efectuarse sino mediante una operación esclarecedora y un pensar consecuente con el fondo original de sus ideas" ${ }^{33}$. Cuando en Latinoamérica hablamos de filosofía liberadora no me cabe pensar en mayor exigencia liberadora que esta invitación a la continua segregación de prejuicios y presupuestos. La filosofía es de ese modo intrínsecamente liberadora o no es filosofía. 
Lo que habrá que ver es si efectivamente Husserl se mantiene fiel al principio radical que anuncia: "El principio de todos los principios, lo único que nos puede salvar de todo dogmatismo: que todo lo que se nos brinda originariamente (por decirlo así en su realidad corpórea) en la «sintuición»», hay que tomarlo simplemente como se da, pero también sólo de los límites en que se da... Toda proposición que no hace más que dar expresión a semejantes datos, limitándose a explicitarlos por medio de significaciones fielmente ajustadas a ellos, es también realmente, un comienzo absoluto, llamado a servir de fundamento en el genuino sentido del término"(A). El último fundamento de nuestras afirmaciones está en lo originario, en lo dado. Si traducimos lo dado originariamente en conceptos y nos ceñimos a lo aprehendido realmente sin salimos de este marco, entonces goza de todos sus derechos la proposición que expresa eso fielmente. Ninguna teoría puede sacar su verdad sino de unos datos originarios.

Intentemos entonces describir fielmente lo inmediatamente dado. Para ello nos propone practicar una epojé radical que cierre completamente todo juicio sobre existencias en el espacio y el tiempo, para obrar una descripción libre de metafísicas y de teorías por más sólidas, admirables y contundentes que nos parezcan $^{\text {hs }}$. ¿ Qué puede, en efecto quedar —se pregunta Husserl一, cuando se ha desconectado el mundo entero, contados nosotros mismos con todo cogitare?" Tomemos enteramente lo que se nos da sin prejuicios. Observamos la relatividad despreciada del mundo. Nuestra tarea exclusiva consistirá en captar precisamente este "río heraclíteo" "it. "En la mismidad de este Río heraclíteo" inmediatamente dado no encuentro datos cromáticos, acústicos y demás datos de la sensación o datos sentimentales, volitivos etc., "antes bien se encuentra la intencionalidad, en la forma familiar acuñada idiomáticamente "yo veo un árbol verde", "escucho el murmullo de las hojas", "huelo sus brotes". No encontramos ahí otra cosa que la "conciencia de" ". Persistamos en este río. Por ejemplo el árbol que veo a través de la ventana me es dado en y por una oleada incesante de esbozos a través de modificaciones incesantes, nunca puede la cosa serme dada de manera absoluta. La cosa que se me da es siempre contingente, pero la corriente de vivencias que constituye la cosa es una evidencia apodíctica que no puede ser según Husserl cuestionada. Además de los datos contingentes que ya apreciaba Hume, lo que encuentra Husserl inmediatamente es el flujo puro de lo vivido, un torrente de estados de conciencia, vivencias o fenómenos. Como no puede recalar en datos contingentes por más inmediatos que sean, como lo que busca es algo absoluto, abandona raudamente la provisionalidad de los datos, su enorme disparidad, como si contingencia e inmediatez fueran incompatibles, para quedarse en la intencionalidad misma como peculiaridad más radical de lo inmediatamente dado. Para permanecer no en la corriente heracliteana del río, sino en el río mismo donde transcurre el chorro mareante de los datos.

Todas las vivencias o fenómenos por diversos que sean: percepción, recuerdo, intuición, juicio, valoración, deseo, voluntad etc. tienen en la aprehensión 
como inmediatamente dada una propiedad común que es la intencionalidad, este constitutivo referirse a algo de todos nuestros actos inmediatos. Hume no se dio cuenta del cartacter intencional de todos nuestros actos inmediatos. Tampoco apreció el sentido que tienen inmediatamente todos nuestros actos. Es decir, gracias a un sinfín de impresiones yo lo que aprecio es un árbol. El sentido para Husserl no es primariamente otra cosa que la unidad de una diversidad de fenómenos particulares, la unidad de los diversos aspectos bajo los cuales aparece una cosa inmediatamente y que sólo apelando a construcciones teóricas puedo diseccionar. Tanto la intencionalidad como el sentido es lo que define a la conciencia. Hay por así decirlo una correlación estricta entre el fenómeno y la conciencia, así la conciencia se reduce a su acto de referirse a un objeto.

El análisis de Hume no apreció ni la intencionalidad, ni el sentido. "Si el empirismo hubiese hecho más honor a su nombre, permaneciendo vinculado a la pura experiencia, no habría podido equivocarse en dar con la reducción fenomenológica, y sus descripciones nunca lo habrían conducido a datos y complejos de datos, y el mundo del espíritu en su peculiaridad y totalidad infinita no le habría quedado cerrado"hy . Aunque se podría discutir la inmediatez de estos dos caracteres, el problema más grave surge cuando se da prioridad al polo subjetivo, al carácter constituyente de la conciencia: "Las unidades de sentido presuponen una conciencia que dé sentido, que por su parte sea absoluta y no exista por obra de un dar sentido" "'). La conciencia aparece ya aquí como un supuesto absolutamente justificado, pero supuesto a fin de cuentas. La conciencia constituyente no es por tanto algo dado inmediatamente en la aprehensión con lo que Husserl parece incumplir el principio radical con el que se había comprometido.

\section{La comprensión}

Comprender para Heidegger no es como en Husserl un ideal metódico último de la filosofía frente a la ingenuidad del ir viviendo, ni es como en Zubiri inteligir en líneas muy diversas la estructuración y la determinación interna de lo que es aprehendido como real ${ }^{11}$, sino que es el modo de ser, la forma originaria del ser en el mundo. Comprender es el carácter más original e inmediato de la vida humana misma y de lo que tratará en Ser y Tiempo es de analizar esta estructura originaria. Para Heidegger tanto la intencionalidad como el sentido husserliano son derivados ya lejanos del "comprender". "También la intuición de la fenomenología se funda en el comprender"72. Lo que encontramos inmediatamente antes que la conciencia constituyente o una relación noetico-noemática es una apertura al ser. El ser humano es precisamente el ámbito de esta apertura, el ámbito del ser. Somos constitutiva apertura, ek-sistencia. Esta apertura radical al ser es justo lo que Heidegger llama comprensión.

La comprensión consiste en la patencia misma del ser, en el estar siendo de la cosa en la aprehensión, previo a todo carácter intencional. La comprensión de 
que nos habla Heidegger es antepredicativa: "todo simple ver antepredicativamente es ya en sí mismo comprensor" "s, y anteintelectiva. La comprensión del ser envuelve tanto la práctica como la teoría. En todo comportamiento hacia las cosas (entes) tanto si es específicamente cognitivo como si es técnico-práctico ya está presupuesta una comprensión del ser. La comprensión nos remite a una estructura original del "dasein" y es importante distinguirla de la comprensión hermenéutica aunque muchos textos de Heidegger abran paso a las filosofías hermenéuticas y a su insalvable lingüisticidad ${ }^{74}$. No es lo mismo el círculo hermenéutico del que nos habla Gadamer del círculo del comprender de Heidegger. Antes que un yo trascendental o una conciencia nos encontramos una vida fáctica, histórica. Antes de la conciencia nos encontramos ya inmersos en la facticidad pre-consciente y pre-reflexiva de la existencia. Antes de que nos comprendamos a nosotros mismos en la reflexión, nos estamos comprendiendo ya en la familia, en la sociedad, en el grupo social en que vivimos. En este sentido tiene razón Gadamer cuando afirma que nuestros prejuicios son, mucho más que nuestros juicios, la realidad histórica de nuestro $\operatorname{ser}^{75}$.

Ver en el círculo del comprender un círculo vicioso y andar buscando caminos para evitarlo, e incluso simplemente "sentirlo" como una imperfección inevitable, significa no comprender, de raíz, el comprender"76. No se trata de ajustar el comprender a un determinado ideal del conocimiento sino al contrario de ajustar este ideal del conocimiento a la estructura radical del comprender del dasein. "Lo importante no es salir del círculo, sino entrar en él del modo justo... Este círculo del comprender no es un círculo en que se movería una cierta forma de conocimiento, sino que es la expresión de la existenciaria estructura del « vio > peculiar al ser ahí mismo" $"$. Este círculo nos dice Heidegger no debe rebajarse al nivel de un círculo vicioso. En él se alberga una positiva posibilidad de conocer en la forma más original, aunque una posibilidad que sólo es empuñada de un modo genuino cuando la interpretación ha comprendido que su primera, constante y última función es evitar que las ocurrencias y los conceptos populares le impongan en ningún caso el "tener", el "ver" y el "concebir" "previos". El "círculo" del comprender no es un círculo lingüístico o lógico sino existencial. El dasein tiene una estructura circular, es un círculo anterior a toda proposición lingüística. Salir de este círculo sería tanto como pretender ser inmortales.

En el análisis de Heidegger de esta estructura originaria destacarían cuatro caracteres. En primer lugar, la constitutiva historicidad del dasein. Esta constitutiva historicidad del Dasein no conlleva una asunción acrítica del pasado, al contrario, abre un espacio para la revisión crítica y para ser de otro modo, pero el punto de partida a diferencia de Husserl no tiene ninguna apodicticidad, es fáctico, histórico. La facticidad pre-consciente y pre-reflexiva de la existencia no es descartada como no inmediata. Al contrario, es tan inmediata que lo más de las veces estamos sumergidos en ella sin damos cuenta. Por tanto, previo al yo trascendental o a la conciencia constitutiva nos topamos con una vida fáctica $e$ 
histórica. En segundo lugar, se nos manifiesta la imposibilidad de establecer en el punto de partida una prioridad del sujeto o de la conciencia sobre lo constituido. No hay en el tomprender ninguna presencia intencional de la cosa, ni ninguna conciencia absoluta que pueda aislarse con total evidencia. Precisamente la conciencia y la intencionalidad penden de la apertura al ser, pues éstas no crean esta apertura, a lo más constituyen una explicación de la misma. La intencionalidad y la conciencia no es posible más que para el ser que tiene ya desde siempre un mundo. En tercer lugar su carácter temporal. La temporalidad de Heidegger no es la de la conciencia. El ser mismo es tiempo. Por esta temporalidad la pertenencia a tradiciones pasadas es tan originaria como la proyección hacia posibilidades futuras. La comprensión original está vinculada tanto a la costumbre, a la tradición y al pasado como a las posibilidades de futuro. $\mathrm{Y}$ en cuarto lugar dilatará lo que debemos entender por sentido. Sentido para Heidegger no dice como en Husserl referencia a una conciencia. Sentido es aquello en que se apoya el "estado de comprensible de algo". Antes que una intencionalidad o una referencia a una conciencia constitutiva lo que nos aparece en lo inmediatamente dado es un sentido.

Por estos elementos de la estructura radical del dasein, de su apertura al ser, es tan ridículo para Heidegger la búsqueda de un punto arquimédico inalterable, de algo eterno, seguro e inmutable donde hacer pie como intentar saltar por encima de la propia sombra, pero no por ello se instala confortablemente en el perspectivismo y particularidad de alguna que otra escuela filosófica, no renuncia a la temeridad de la aventura filosófica, sino que asumiendo precisamente la constitutiva historicidad y particularidad de cualquier filosofía ve en esta particularidad e historicidad el principal acicate para elaborar nuevas y radicales respuestas a la cuestión de la verdad primera.

\section{La impresión de realidad}

Apertura, nos dirá Zubiri, no es comprensión sino impresión ${ }^{78}$. El hombre no es "comprensor del ser", no es morada y pastor del ser, sino animal de realidades. "En el fondo, toda la filosofía de Heidegger es un comentario a esta idea de que el hombre es el comprensor del ser. No es de extrañar. Heidegger ha partido de la fenomenología, y pese a las hondas, radicales, transformaciones que en ella introduce, permanece en el ámbito fenomenológico. Para la fenomenología, lo primario y fundante es siempre y sólo la conciencia, como ente en el cual y sólo en el cual se dan las cosas en lo que ellas verdaderamente son. Heidegger supera la idea de conciencia mediante la idea de comprensión, y supera la idea del darse de las cosas mediante la idea del mostrarse"7y. Zubiri insistirá en que en una descripción rigurosa de lo dado, antes de la historicidad, la instalación en un mundo, la temporalidad y el sentido, damos con la "cosa-realidad". "Heidegger insiste en pensar que aprehendemos mesas, sillas - cosas sentido-, cuando lo que aprehendo es una constelación de notas que en mi vida funcionan como mesa" ${ }^{\text {"\$I }}$. 
El análisis de Zubiri pretende ser una descripción previa al sentido que las cosas puedan tener en la aprehensión. En cierto modo Zubiri preconiza un retorno y una reconsideración rigurosa de Hume. Hume vio muy bien que lo formalmente constitutivo del sentir es la impresión, lo que no hizo fue conceptuar con rigor qué es impresión. No se percató de que esta impresión tiene una estructura, que cabe distinguir en ella un momento de afección, un momento de alteridad y un momento de fuerza de imposición ${ }^{\mathrm{H1}}$.

Por el momento de afección podemos decir que lo sentido (colores, sonidos, temperatura etc.) afecta al sentiente, es algo padecido por él. Zubiri nos dirá que la filosofía antigua y moderna prácticamente sólo ha recabado en este momento de la impresión y la consecuencia fundamental de privilegiar este momento de la impresión es que quedamos atrapados en el subjetivismo. Es el caso de Hume en que lo aprehendido es pura afección mía y, por tanto, carente de todo tipo de reivindicación de sus fueros como realidad autónoma e independiente en la aprehensión misma. La impresión se convierte en pura afección del sujeto. No es de extrañar entonces que el empirismo asuma acríticamente el prejuicio nominalista de pensar que lo mental, la idea, la significación tienen que ser reducidos a algo palpable, a sensación, a afección sensitiva como si un dolor, un color o un sonido tuvieran mayor inmediatez que un triángulo, un recuerdo o una fantasia ${ }^{82}$. De esta suerte se pensará que estos últimos no son impresiones. A Zubiri incluso le parecerá algo inadecuada la noción de "impresión”, pues al estar de hecho ligada con el momento afectante tiende a resaltarlo frente a los otros dos ${ }^{83}$. Pero nombremos como nombremos a lo inmediatamente presente, lo decisivo para Zubiri es que apenas se ha recabado en los otros dos momentos. No obstante, justo es reconocer que Zubiri por más que declara importantísimo el momento de imposición y su voluntad de demorar en él, prácticamente sólo se dedica a analizar la alteridad ${ }^{\text {ta }}$.

Por el momento de alteridad, lo aprehendido, sea lo que sea (triángulo, fantasía, sonido, dolor, emoción), queda como "otro" en la aprehensión misma. El contenido de lo aprehendido está presente como otro en la aprehensión. Tiene un aspecto de independencia, queda como autónomo. Si dislocamos este momento, se puede caer fácilmente en el idealismo, porque lo aprehendido pierde su carácter real ${ }^{\mathrm{BS}}$ y queda reducido a mera alteridad, estableciéndose un hiato insalvable entre la alteridad y la realidad. Es decir, si la realidad no la alcanzamos inmediatamente, no se ve cómo se puede alcanzar después. Y es que Zubiri entiende la alteridad desde la presencia de las cosas como "de suyo" en la aprehensión, y no a la inversa. Este estar "de suyo" de las cosas en la aprehensión no creo que sea exactamente sinónimo del momento de alteridad para Zubiri, aunque muchas veces la expresión sea utilizada como equivalente. Y ello por dos razones. En primer lugar porque la alteridad es una expresión mucho más ambigua e imprecisa que “de suyo". La alteridad Hegeliana, por ejemplo, lo acaba engullendo todo en una conciencia absoluta, la alteridad en Marx ${ }^{86}$ y en Levinás nos abocan 
inmediatamente a la exterioridad. Alteridad para ellos es sinónimo de trascendencia, de otreidad, mientras que para Zubiri la alteridad es el estar de las cosas en la aprehension no como meramente otras, sino como "de suyo". Y en segundo lugar porque la alteridad es un momento del "de suyo" que forma una precisa estructura con el momento afectante e impositivo.

Por el momento de imposición lo aprehendido se impone al sentiente independientemente de la intensidad de la afección. El más leve sonido, si nos están persiguiendo, tiene un pavoroso poder impositivo, mientras que un temblor nos puede dejar más o menos impávidos en un país como Nicaragua donde estamos acostumbrados a ellos. Hay, por decirlo así, un poder de lo real que nos fuerza a realizar actos de todo tipo (afectivos, volitivos, perceptivos). Si olvidáramos este momento, nuestras afirmaciones y nuestros actos serían espontáneos en lugar de depender, de estar forzados por una primaria imposición de lo real ${ }^{87}$. Y si privilegiamos este momento por encima del otro, fácilmente podemos deslizamos hacia filosofías del poder que privilegien el cuerpo, la sensibilidad, la vida o la deidad como fuerzas e instancias rectoras últimas de los actos humanos.

Esta impresión, con estos tres momentos estructurales, es aprehendida como algo que es de suyo. $Y$ este tipo de impresión es estrictamente sinónimo de realidad. Como realidad para Zubiri significa simple ser "de suyo" y es una noción que contrasta con el uso filosófico del término realidad, utiliza el término "reidad" para evitar que se le confunda con cualquier tipo de realismo ingenuo. "No se trata de ir allende lo aprehendido en la aprehensión sino del modo como lo aprehendido queda en la aprehensión misma"»\&. He aquí un texto muy aclaratorio: "Realidad no es, pues, independencia objetiva ni es tampoco existencia. Mucho menos aún es algo que esté allende lo sentido. Ciertamente hay infinitas cosas allende lo sentido, pero estamos llevados a admitirlas, estamos llevados a ellas, por intelección sentiente de lo que es aprehendido de suyo. Sus notas son por esto reales, pero esto no significa, que sean reales «sfuera»s de la percepción. Hacer de lo real, en la aprehensión de una cosa real en el mundo, algo allende la aprehensión, puede ser como ya ha sido millones de veces en la historia una grave forma de error. Realidad no es existencia allende la aprehensión. Aquende y allende son dos zonas de cosas reales, pero realidad no es aquende ni allende. Realidad no es sino puro de suyo, no es una zona de cosas. Por esto la división de cosas allende y aquende la percepción se funda en la impresión de realidad y no al revés" terminología antigua y literalmente inadecuada" ${ }^{\left({ }^{*}\right)}$ como inmanente y trascendente, interior y exterior, que quizás no se subsane con su substitución por aquende y allende. En el análisis de mis actos aprehensivos llego a una situación primera donde siento las cosas como de suyo, se trata de una presencia física, actual. La realidad nos es dada en la aprehensión, desde esta realidad misma aprehendida vamos hacia la realidad no aprehendida ya sea esta interna o externa, aquende o allende. Lo real posible no inmediatamente dado sólo es inteligi- 
ble en conexión con lo dado inmediatamente. Si en lo inmediatamente dado no se abriera el ámbito de la realidad, si no estuviéramos instalados inmediatamente en la realidad, la razón no la alcanzaría nunca y no sólo esto, sino que la razón gozaría de una primariedad y espontaneidad más que discutible ${ }^{91}$.

Con todo esto no hemos salido de la inmediatez de la aprehensión pero, a diferencia de Hume, la impresión de realidad es constitutiva apertura de un contenido a todo otro contenido concreto, y además es apertura al mundo, apertura hacia toda otra cosa real. Esta apertura, por la que toda cosa real en la aprehensión remite desde sí misma a otras cosas reales estén o no presentes en la aprehensión es un dato, un hecho positivo en el que Hume no reparó. Y en esto consiste la trascendentalidad de la realidad, en la apertura de cada una de las realidades a toda otra realidad. El problema racional, por tanto, no consiste en alcanzar la realidad ni en alcanzar el mundo, sino en ir experimentando y conociendo el contenido de la realidad y del mundo. Este contenido es siempre problemático y caben muchas teorías científicas y metafísicas, pero ellas son justamente posibles por la impresión de realidad dada y su peculiar estructura.

\section{El acto}

La crítica decisiva de Antonio González a Zubiri más allá de la conveniencia o no del término "realidad" en función de su uso tradicional, es que Zubiri se desplaza hacia un carácter trascendental de los actos y no permanece en los actos mismos. El problema no es sólo que con el término "realidad" Zubiri mente tanto el carácter de alteridad con que las cosas se nos actualizan en los actos humanos como el carácter de las cosas tal como son con independencia de ellos. Antonio González tampoco asumiría como punto de partida lo que Zubiri llama reidad, la alteridad radical con la que las cosas se nos actualizan en nuestros actos. Lo que plantea Antonio González no es simplemente una cuestión terminológica o de precisión. Aunque mostráramos que el último Zubiri entiende "realidad" sin anfibologías como la designación que recibe el hecho de que todo acto se actualiza como de suyo en la aprehensión, Antonio González nos diría que no se instala en los actos mismos. Esta realidad o alteridad radical es siempre para Zubiri un carácter que tienen las cosas en los actos mismos, pero los actos mismos son anteriores y primarios respecto a la "realidad" u "alteridad radical" de las cosas en la aprehensión. "Por mucho que la alteridad radical nos remita más allá de nuestros actos, ella es siempre un carácter que tienen las cosas en los actos mismos. Hay una anterioridad del acto que se presenta y del acto en el que se presentan sobre el modo de presentarse y no a la inversa. Los actos son anteriores a esa alteridad radical que Zubiri denomina realidad' ${ }^{\text {'92 }}$.

El punto de partida radical para Antonio González son los actos humanos en toda su variedad y multiplicidad, ya sean intelectivos, perceptivos o afectivos, actos de reposo o contemplación o actos que intentan modificar algo. Una filo- 
sofía primera que sea tal, no puede privilegiar, a no ser que mantenga una teoría antropológica implícita, ningún tipo de actos, tampoco podemos deslizamos a ninguna instancia por detrás o debajo de estos actos ya sea una substancia, un sujeto, un yo, una conciencia o la "realidad" zubiriana porque por más obvio o legítimo que pueda ser todo ello no goza de la inmediatez de los actos mismos.

La noción de acto debe desligarse en una filosofía primera de toda metafísica tanto aristotélica (acto como plenitud de algo o realización de una potencias) como escolástica (operación de una sustancia) o moderna (actividad de un sujeto o sujetos). Se trata de tomar los actos en sí mismos, en su inmediatez. Lo característico de todos los actos humanos es que en ellos se presentan cosas o personas como algo otro respecto a los actos mismos y como en ellos no sólo tenemos los contenidos sentidos de las cosas, sino que además estos contenidos se presentan en nuestras impresiones como radicalmente distintos de ellas. Señalará Antonio González que esta apreciación de la alteridad de las cosas en nuestros actos es lo que nos permite evitar el error de Hume y considerar los actos como actos y no como cosas, pudiendo así aferramos a la inmediatez de los mismos. La filosofía primera, en lugar de sumergimos en el contenido de la cosa actualizada a lo que nos empuja la misma alteridad radical, debe intentar describir el acto de actualización misma en su pura ejecución.

Por ello Antonio González insistirá en que la verdad primera es la verdad simple del acto en su pura ejecución y que esta verdad simple es anterior a toda dualización y aún anterior a la verdad real que consiste en la actualización de las cosas en la aprehensión, que es una verdad que se mueve en el interior del acto mismo. Antes de la verdad real se encuentra la verdad simple de la ejecución del acto. Esta verdad primera es una verdad fáctica, pues podría ser siempre de otra manera, pero es impropio llamarla verdad contingente; en primer lugar, porque es necesario e inexorable que actuemos siempre; en segundo lugar, porque tiene un carácter trascendental: los actos son inmediatos para todos y a la vez se pueden establecer funcionalidades y estructuraciones entre ellos, y en tercer lugar, porque tienen un carácter absoluto en la medida en que una vez ejecutados son irreversibles.

Ahora bien, si para alcanzar la verdad primera tenemos que permanecer precisamente en los actos mismos, ¿es cierto que alcanzamos la pura ejecución del acto permaneciendo en el acto mismo? No está nada claro que si nos atenemos a lo dado inmediatamente en el acto la verdad primera sea la facticidad primordial del acto. Una cosa es el carácter ejecutivo del acto en el sentido en que nos hablaba de ello Ortega y Gasset, otra la consideración de este acto como algo hecho, ejecutado. Parece que para determinar la pura ejecución del acto tengo que deslizarme fuera de la inmediatez del acto mismo. El hecho primordial del que nos habla Antonio González pretende ser previo a todo positum u hecho positivo en el sentido zubiriano, ¿pero es realmente más inmediato o es un supuesto de éstos? 
Una segunda dificultad es que al dislocar en el acto el momento de alteridad de los otros dos momentos que nos descubría en el análisis Zubiri, sucede exactamente lo que prevé Zubiri, se pierde la realidad. Si una de las características de ciertos idealismos es que además del mundo inteligido se admite la existencia de otro mundo real, radicalmente distinto del primero y que nunca podrá llegar a ser contenido por la conciencia, es decir que se establece un hiato o abismo infranqueable entre la subjetividad y la realidad, en la praxeología trascendental de Antonio González la subjetividad es sustituida por los actos humanos, pero el hiato es el mismo. No se ve cómo puedo pasar de la alteridad radical a la realidad o más bien nunca puedo acceder a ella sino sólo suponerla dejándome sumergir en la alteridad radical. Con toda la gravedad esto no deja de ser una crítica muy superficial, lo que hay que analizar es si efectivamente se da este hiato o si la realidad es alcanzable en el acto mismo, independientemente de los calificativos que reciba y de las consecuencias que vaya a tener una u otra solución. La cuestión está en ver qué análisis es más fiel a lo inmediatamente dado, si son análisis incompatibles, si hay en Antonio González una efectiva radicalización del análisis zubiriano, o si más bien lo que hace es añadir a lo ganado por Zubiri cuestiones importantísimas como es la extensión del análisis de los actos de aprehensión a todo tipo de acto.

Ciertamente la pregunta por la existencia y realidad del mundo y del sujeto no es una cuestión que deba plantearse una filosofía primera radical puesto que son preguntas que nos llevan más allá de la inmediatez de los actos mismos. Sin embargo, la "reidad" de la que nos habla Zubiri nada tiene que ver con la existencia clásica y tampoco como ya hemos visto es exactamente sinónima de la alteridad radical con la que se nos presentan los actos. El problema decisivo —según Antonio - es que la "reidad" nos hace "trascender los actos" ir más allá de los mismos, sin embargo tampoco esto es tan claro en Inteligencia y realidad. Es decir no veo en la crítica de Antonio González una objeción decisiva al "de suyo" Zubiriano, aunque sí una enorme ayuda para su precisión, clarificación y exactitud, más allá de la ambivalencia a la que dan pie algunos textos.

\section{Conclusiones}

En el inicio hemos establecido tanto la relevancia como la posibilidad de acceder a una verdad primera atendiendo sobretodo a las objeciones del racionalismo crítico y de la filosofía hermenéutica. Después hemos examinado muy someramente como ha sido descrita esta verdad primera por Hume, Husserl, Heidegger, Zubiri y Antonio González y hemos podido observar un cierto aunque dificultoso avance en esta descripción, una especie de descomunal diálogo platónico lleno de segundas navegaciones y de naufragios. En Hume hemos reconocido la finura de su argumentación y su esfuerzo por permanecer en lo estrictamente dado pero no advierte el momento de alteridad de la impresión. Nos hemos entusiasmado con Husserl por la radicalidad de su proyecto filosófi- 
co y hemos visto como ganancia respecto al análisis de Hume de lo inmediatamente dado la intencionalidad y el sentido, pero hemos reparado en un desliz hacia un yo trascéndental o conciencia constituyente, hacia un Yo puro que se estima en la corriente de las impresiones como lo único que puede constituirse en un ámbito trascendental y que no se ciñe a lo que Husserl anuncia como el principio de todos los principios. Ateniéndose a este principio pareciera que no podía ganar ningún ámbito trascendental, esto es apodíctico y universal. En Heidegger hemos resaltado cuatro caracteres de la estructura originaria del "estar-ahí": la historicidad, la instalación en un mundo, la temporalidad y el sentido que constituyen la trascendentalidad del ser y aunque estos caracteres puedan ser más originarios que el Yo trascendental Husserliano, nos queda la duda de que sea fiel al principio anunciado por Husserl de atenemos a las cosas tal como se dan y en los límites en que se nos dan en la aprehensión, principio que hemos asumido como decisivo para una filosofía primera.

Zubiri nos incita a mantenemos en la radicalidad de Hume mostrándonos la precisa estructura de la impresión. Esta impresión nos instala inmediatamente en la realidad y desde esta inmediatez de la realidad vamos hacia la realidad no aprehendida, ya sea ésta interna o externa, aquende o allende y podemos, en definitiva, librar algunas esquirlas de inteligibilidad de la misma. Pretende conquistar con ello un ámbito de trascendentalidad inmediatamente dada consistente en la pura apertura o comunicabilidad de la realidad a toda otra cosa. Antonio González insiste en que permanezcamos en el río heraclíteo mismo de los actos sin deslizamos hacia algún carácter de todos ellos o peor hacia un supuesto de los mismos, pues justamente lo más inmediato y absoluto, el ámbito de trascendentalidad más radical, lo hallamos en la facticidad de nuestros actos. La objeción más grave que mantenemos es si esta verdad primera, la facticidad de los actos primordiales, es de hecho alcanzable en el análisis del acto mismo.

Como quiera que sea, la dilucidación de estas dudas no pueden venir de discusiones de escuela, sino del estudio y descripción rigurosa de lo inmediatamente dado en diálogo con todos los que en la historia de la filosofía han arribado a esta esfera de radicalidad. Si es cierto que cualquier pequeño matiz en el punto de partida se convierte después en posiciones divergentes y hasta incompatibles, bueno será permanecer en el laberinto y en la aparente esterilidad e infructuosidad del análisis de lo inmediatamente dado, de la determinación de una verdad primera, cargando con todas nuestras dudas y temores sin precipitación alguna por salir del laberinto, porque quizás sólo así, con paciencia y calma, sin dejamos engañar por las vías aparentemente rápidas y expeditas, encontremos el camino de la verdad.

\section{Notas}

1. A. González, Estructuras de la praxis, Madrid, Trotta, 1997.

2. Op. cit., p. 13. 
3. R. Rorty, Consecuencias del pragmatismo, Ed. Tecnos, Madrid, 1996.

4. Ibid., p. 57.

5. Es lo que nos mostró Antonio González en su curso Filosofia primera y teoría social, UCA, Managua, agosto, 1996.

6. "Y pretendo penetrar hasta tanto conozca algo cierto, $o$ al menos tenga por cierto que no hay nada cierto. Arquímedes sólo pedía un punto firme e inmóvil para mover de su sitio toda la tierra, y así debo esperar algo grande cuando logre lo ínfimo que es seguro e inconmovible", R. Descartes, Meditaciones, Alfaguara, Madrid.

7. Albert Hans, Tratado sobre la razón crítica, Ed. Sur, Buenos Aires, 1973, p. 27.

8. O. Apel, Teoría de la verdad y ética del discurso, Paidós, Madrid, p. 113 y ss.

9. Albert Hans, op. cit., p. 59.

10. Una amplia discusión sobre el asunto puede encontrarse en el libro de O. Apel, Teoría de la verdad y ética del discurso, op. cit., que pretende precisamente fundamentar y dar sentido al falabilismo.

11. O. Apel, La transformación de la filosofia, Taurus, Madrid, p. 267 y ss.

12. E. Gadamer, Verdad y método, Ediciones Sígueme, Salamanca, 1977, p. 337.

13. Ibid., p. 343.

14. P. Ricoeur, Finitud y culpabilidad, Ed. Taurus, Madrid, p. 496.

15. "La realidad se nos impone con la fuerza de tener que dotarla de un contenido". $X$. Zubiri, Inteligencia y razón, Alianza Editorial, Madrid, p. 179.

16. "La profundidad tiene hondura insondable. La intelección en profundidad es un hecho, pero el acceso a la ultimidad es constitutivamente un problema siempre abierto hasta el infinito", X. Zubiri, ibid., p. 168.

17. Los hechos positivos a diferencia de aquello positivamente actualizado en la aprehensión (positum) y de los hechos científicos son precisamente datos que por su propia índole son aprehendibles por cualquiera. Para una distinción crucial entre positividad, hecho positivo y hecho científico, ver X. Zubiri, Inteligencia y razón, ibid., p. 181 y ss.

18. X. Zubiri, Inteligencia y realidad, Alianza Editorial, Madrid, p. 14.

19. "La ciencia de lo radical también tiene que ser radical en su proceder y desde sus puntos de vista.... por ello es preciso no explicar lo visto por la coacción de los prejuicios", E. Husserl, La filosofia como ciencia estricta, Editorial Nova, Argentina, 1962, p. 19.

20. Aquí sigo la crítica rigurosa a la que somete Antonio González la filosofía hermenéutica de Gadamer en su libro de próxima publicación Filosofía primera y del que amablemente nos cedió los originales.

21. E. Gadamer, Verdad y método, op. cit., p. 344.

22. Ibid., p. 344.

23. Ferreter Mora, Diccionario de filosofia.

24. Filosofía primera y teoría sociAlianza Curso de postgrado de Antonio González, Managua, UCA, agosto, 1996.

25. L Witggenstein, Imestigaciones filasóficas, UNAM, Ed. Crítica, México, pp. 654655.

26. Aquí discrepamos de la interpretación de Wittgenstein que realiza Apel. Según él para el II Wittgesntein toda conducta humana pende siempre de un juego lingüístico y no a la inversa. Ver O. Apel, La transformación de la filosofia, op. cit., p. 355.

27. Esta expresión mueve a muchos equívocos. Aquí la entendemos en sentido Zubiriano como sinónimo de actualidad en la aprehensión y no, por decirlo así, como algo 
medible, materiAlianza Ver X. Zubiri, Inteligencia y Realidad, Alianza Editorial, p. 22.

28. Es lo que prołone Rorty. Ver R. Rorty, "Cultura postfilosófica", Consecuencias del pragmatismo, Tecnos, Madrid, 1996, p. 51 y ss.

29. D. Hume, Tratado sobre la naturaleza humana, Ed. Guernika, Bilbao, 1987, p. 11.

30. Ibid., p. 35.

31. Ibid., p. 248.

32. Ibid., p. 326.

33. Ibid., p. 221.

34. Ibid., p. 220.

35. Ibid., p. 242.

36. Ibid., p. 246.

37. Ibid., p. 12.

38. Ibid., p. 17.

39. Ibid., p. 223.

40. Ibid., p. 221.

41. Husserl nos previene de las dificultades para evitar una y otra vez la recaída en los prejuicios del naturalismo. E. Husserl, La filosafia como ciencia estricta. op. cit., p. 13.

42. D. Hume, op. cit., p. 303.

43. X. Zubiri, Inteligencia y logos, Alianza Editorial, Madrid, pp. 39-41.

44. Ibid., p. 35.

45. J. Ortega y Gasset, Unas lecciones de metafisica, Alianza Editorial, Madrid, p. 207.

46. Ibid., p. 207.

47. Ibid., p. 210.

48. Ibíd., p. 220.

49. D. Hume, op. cit., p. 255.

50. Ibid., p. 256.

51. Antonio González. Apuntes Filosofía primera.

52. E. Husserl, La filosofia como ciencia estricta, op. cit., p. 42.

53. E. Husserl, Ideas relativas a una fenomenologia pura y una filosofia fenomenológica, FCE, 1986, p. 389.

54. E. Husserl, La filosofía como ciencia estricta, p. 48.

55. Ibid., p. 50.

56. E. Husserl, La crisis de las ciencias europeas y la fenomenología trascendentah, Folios ediciones, Buenos Aires, p. 73 y 93.

57. Ibid., p. 12.

58. E. Husserl, La filosofía como ciencia estricta, op. cit., p. 51.

59. E. Husserl, Ideas relativas a una fenomenologia pura y una filosofia fenomenológica, FCE, 1986, p. 142.

60. E. Husserl, La filosofia como ciencia estricta, op. cit., p. 52.

61. E. Husserl, Crisis de las ciencias europeas y la fenomenología trascendental, op. cit., p. 78.

62. E. Husserl, “\& Como Descartes falla al girar en sentido trascendental”, Meditaciones cartesianas, FCE, 1986, p. 66.

63. E. Husserl, Ideas relativas a una fenomenología pura y una filosofla fenomenológica, FCE, 1986, p. 81. 
64. E. Husserl, ibid., p. 58.

65. E. Husserl, ibid., p. 73.

66. E. Husserl, ibid., p. 75.

67. E. Husserl, ibid., p 158

68. E. Husserl, Crisis de las ciencias europeas y la fenomenología trascendental, op. cit., p. 231.

69. Ibid., p. 246.

70. La cursiva es del autor. Ibíd., p. 128 y ss.

71. X. Zubiri, Inteligencia y Razón, op. cit., p. 334 y ss.

72. M. Heidegger, Ser y tiempo, FCE, 1967, p. 185.

73. Ibíd., p. 167.

74. "La interpretación de algo como algo tiene sus esenciales funciones en el «tener»>, el «ver»> y el «<oncebir»» «previos»». Una interpretación jamás es una aprehensión de algo dado llevada a cabo sin supuestos. Cuando esa especial concreción de la interpretación que es la exacta exégesis de textos gusta de apelar a lo que «<ahí está »>, esto que «<ahí está»> inmediatamente no es nada más que la comprensible de suyo, la no discutida opinión previa del intérprete, que interviene necesariamente en todo conato de interpretación". M. Heidegger, ibid., p. 169.

75. Pero fijémonos que aquí el prejuicio no es lingüístico. E. Gadamer, op. cit., p. 344.

76. M. Heidegger, Ser y tiempo, p. 171.

77. Ibid., p. 171.

78. X. Xubiri, Sobre la esencia, Alianza Editorial, Madrid, p. 452.

79. Ibid., p. 452.

80. X. Zubiri, Inteligencia y realidad, op. cit., p. 59.

81. X. Zubiri, Inteligencia y realidad, op. cit., p. 32 y ss.

82. Véase la perspicaz crítica de Husserl al prejuicio nominalista asumido por los empiristas. E. Husserl, Investigaciones lógicas, Biblioteca de la Revista de Occidente, Madrid, 1976, \&24 ss.

83. X. Zubiri, Hombre y Dios, Alianza Editorial, Madrid, p. 34.

84. X. Zubiri, Inteligencia y realidad, op. cit., p. 34.

85. Ibid., p. 66.

86. K. Marx, Manuscritos de 1844, UCA Editores, p. 127 y ss.

87. X. Zubiri, Inteligencia y realidad, op. cit., p. 66.

88. X. Zubiri, ibid., p. 58 y ss.

89. X. Zubiri, Hombre y Dios, op. cit., p. 38 y ss.

90. X. Zubiri, Inteligencia y realidad, op. cit., p. 58.

91. "La realidad no es algo que necesite ser alcanzado por la razón como si se tratara de pasar de un concepto de realidad a lo real de las cosas, sino que la realidad como campo físico es aquello que intrínseca y formalmente pertenece a la intclección de lo real en la razón". X. Zubiri, Inteligencia y razón, op. cit., p. 54.

92. Antonio González. Apuntes Filosofía primera. 